\title{
Kesuburan Tanah dan Produktivitas Padi pada Budidaya Organik, Semi Organik, dan Konvensional di Kabupaten Sragen
}

\author{
Sukristiyonubowo Sukristiyonubowo ${ }^{1^{*}}$, Damas Riyanto², Sugeng Widodo ${ }^{3}$ \\ ${ }^{1}$ Balai Penelitian Tanah, Indonesian Agency for Agricultural Research and Development, Bogor, Indonesia \\ 2,3Balai Pengkajian Teknologi Pertanian Yogyakarta, Indonesian Agency for Agricultural Research and \\ Development, Sleman, Indonesia
}

*Corresponding Author:

E-mail: sukristiyonuboworicky@yahoo.com

Received 19 July 2019; Accepted 15 November 2019; Published 30 December 2019

\begin{abstract}
The farmers realize that Green Revolution technology with external inputs (mineral fertilizer and pesticide) is no longer sustainable and cost production become too expensive. The farmers want to move to organic, semi organic and some remain doing conventional farming system. The aim of the research was to study the dynamic of soil fertilities and biomass production under organic, semi organic and conventional rice farming systems. The study was conducted in Termes Village Sambung Macan Sub District, Sragen District, Central Java and Analytical Laboratory of the Yogyakarta Assessment Institute for Agricultural Technology from March 2017 to 2018. Soil composites were taken in March 2017 and in 2018 at organic, semi organic and conventional rice farming systems. The results showed that in general the soil chemical fertility taken in 2018 under three rice farming were better than soil sampled in 2017 including $\mathrm{pH}, \mathrm{C}$ organic, $\mathrm{N}$ total, $\mathrm{P}$ and $\mathrm{K}$ extracted with $\mathrm{HCl} 25 \%$. The same results were happened in rice biomass production, in organic rice farming was more excellent compared to semi organic and conventional rice farming and in semi organic was better than conventional rice farming because of soil C-organic content were higher.
\end{abstract}

(C) 2019 Agrotechnology Research Journal

Keywords Farming Systems; Fertilizer; Yield

Cite This As: Sukristiyonubowo S, Riyanto D, Widodo S. 2019. Kesuburan Tanah dan Produktivitas Padi pada Budidaya Organik, Semi Organik, dan Konvensional di Kabupaten Sragen. Agrotech Res J 3(2): 93-96. https://doi.org/10.20961/agrotechresj.v3i2.32508

\section{PENDAHULUAN}

Teknologi revolusi hijau, kombinasi antara input eksternal yang tinggi (pupuk dan pestisida) dan varietas unggul bersifat tidak berkelanjutan, biaya produksi tinggi dan produksi cenderung menurun. Hal tersebut mendasari petani beralih ke sistem pertanian organik, dan semi organik (Sukristiyonubowo et al. 2018). Istilah organik mengacu pada proses yang menggunakan metode yang memperhatikan lingkungan, dari tahap produksi hingga penanganan dan pemrosesan. Sistem budidaya organik, tidak menggunakan pupuk kimia dan pestisida komersial, hanya bergantung pada input organik dan daur ulang untuk pasokan nutrisi, dan menekankan pada desain sistem penanaman serta proses biologis untuk pengelolaan hama (Rigby dan

This is an open access article Licensed under the Creative Commons Attribution International License CC-BY-SA 4.0

(c)) $\mathrm{EY}$-SA
Caceres 2001). Budidaya padi semi organik berarti bebas dari menggunakan produk kimia, tetapi petani masih menggunakan Urea sebanyak $50 \mathrm{~kg} \mathrm{ha}^{-1}$ pada 21 hari setelah tanam. Sistem pertanian padi konvensional yaitu masih menerapkan teknologi revolusi hijau seperti menggunakan pupuk mineral dan pestisida komersial. Di Indonesia, hasil dan kualitas sistem pertanian padi dan sayuran organik lebih baik daripada konvensional.

Di beberapa negara, penelitian dalam sistem pertanian organik telah dikembangkan baik dalam skala plot, usaha tani dan komunitas dengan tujuan yang berbeda. Beberapa keunggulan pertanian organik dilaporkan oleh para peneliti. Menurut Sukristiyonubowo et al. (2018), kesuburan kimia-fisik tanah di lahan organik di Desa Kopeng, Kabupaten Semarang, lebih unggul dari pada di sistem pertanian sayuran konvensional termasuk $\mathrm{pH}$ tanah, $\mathrm{C}$ organik dan $\mathrm{N}, \mathrm{P}$ dan $\mathrm{K}$ total, bulk density, kepadatan partikel, porositas tanah dan permeabilitas (drainase lambat dan 
cepat). Di Kabupaten Bogor, sifat kimia tanah, fisik dan biologis budidaya sayuran organik lebih baik dari pada sistem pertanian konvensional dalam hal $\mathrm{pH}$ tanah, $\mathrm{C}$ organik, $\mathrm{N}$ total, $\mathrm{P}$, dan $\mathrm{K}$ diekstraksi dengan $\mathrm{HCl} 25 \%$, kepadatan massal dan enzim dehidrogenase (Sukristiyonubowo et al. 2015). Hasil serupa dilaporkan pada pertanian padi di Kecamatan Sambiredjo, Kabupaten Sragen, kesuburan kimia-fisik tanah di lahan organik di Kecamatan Sambiredjo, Kabupaten Sragen, lebih unggul dari pada semi organik dan konvensional serta sistem pertanian semi organik lebih baik daripada sistem konvensional dalam hal $\mathrm{pH}$ tanah, $\mathrm{C}$ dan $\mathrm{N}$ organik, total $\mathrm{P}$ dan $\mathrm{K}$, bulk density, kepadatan partikel, porositas tanah dan permeabilitas. Temuan serupa juga diamati dalam produksi biomassa padi. Pertanyaan penelitian selanjutnya adalah berapa lama sistem pertanian organik tanpa input eksternal menopang produksi dan kesuburan tanah (Sukristiyonubowo et al. 2018). Selanjutnya, Prakhas et al. (2002) melaporkan bahwa padi yang ditanam dalam teknologi organik memiliki kualitas penggilingan dan memasak yang lebih baik seperti pemulihan total dan penggilingan beras kepala, kandungan protein, perpanjangan kernel dan kandungan amilosa yang lebih rendah dari pada sistem konvensional. Dilaporkan bahwa kandungan protein yang lebih tinggi akan menghasilkan dan kandungan amilosa yang lebih rendah. Chino et al. (1987) menemukan bahwa dalam budidaya organik, kandungan getah floem tanaman asparagine jauh lebih rendah dari pada sistem konvensional. Kepadatan Brown Plant Hopper dan White Backed Plant Hopper dalam budidaya organik sangat rendah (Kajimura et al. 1995; Alice et al. 2004).

Tingkat aktivitas biologis dan bahan organik tanah lebih tinggi pada budidaya organik daripada teknologi revolusi hijau (Oehl et al. 2004; Mader et al. 2002; Hansen et al. 2000; Stolze et al. 2002). Namun demikian, masih terbatas studi yang membandingkan antara sistem organik dan konvensional (Hasegawa et al. 2005). Dalam sistem pertanian padi konvensional, pengelolaan pertanian yang menguntungkan dan berkelanjutan harus diatasi dengan menyediakan input nutrisi yang cukup untuk pertumbuhan dan perkembangan tanaman yang optimal dengan menjaga lingkungan. Penambahan input untuk jumlah nutrisi yang tepat harus didasarkan pada karakteristik status kesuburan tanah dan jenis tanaman. Tujuan penelitian ini untuk mempelajari dinamika kimia-fisik tanah pada budidaya organik, semi organik dan konvensional di Desa Termes, Kecamatan Sambung Macan, Kabupaten Sragen.

\section{BAHAN DAN METODE}

Penelitian dilaksanakan di Vertisols Sambung Macan Kabupaten Sragen untuk sistem budidaya padi konvensional, semi organik dan organik pada bulan Maret 2017 sampai 2018. Budidaya padi semi organik, menggunakan pupuk nitrogen $50 \mathrm{~kg} \mathrm{ha}^{-1}$ musim $^{-1}$ pada umur padi 21 hari setelah tanam. Budidaya padi organik menggunakan pupuk kandang dari kotoran sapi 3 ton ha-1 musim-1. Dalam sistem konvensional, menggunakan pupuk mineral $200 \mathrm{~kg} \mathrm{ha}^{-1}$ urea, $100 \mathrm{~kg}$ ha-1 phonska, $50 \mathrm{~kg} \mathrm{KCl} \mathrm{ha-1} \mathrm{musim-1} \mathrm{dan} \mathrm{kompos}$ jerami 0,5 ton ha-1. Percobaan ini menggunakan Rancangan Acak Kelompok (RAK) yang diulang 3 kali dengan ukuran petak 2,5 m x 2,5 m. Padi yang digunakan yaitu varietas Ciherang. Transplanting dilakukan pada 21 hari setelah persemaian dengan jarak tanam $25 \mathrm{~cm} \times 25 \mathrm{~cm}$, sebanyak 3 bibit per lubang tanam. Produksi biomasa padi meliputi hasil gabah, jerami, dan sisa panen diamati. Produksi per hektar dihitung berdasarkan hasil biomas padi ubinan 2,5 m x 2,5 m secara acak untuk setiap plot. Padi dipotong sekitar 10 sampai $15 \mathrm{~cm}$ diatas permukaan tanah. Pada kadar air benih sekitar $14 \%$ digunakan untuk penetapan produksi gabah. Prosedur yang sama dilakukan untuk tahun 2018.

Sampel tanah diambil secara komposit pada kedalaman 0-20 cm. Analisis tanah dilakukan di Laboratorium Balai Pengkajian Teknologi Pertanian di Yogyakarta. Analisis tanah meliputi: sifat kimia yaitu $\mathrm{pH}$ $\left(\mathrm{H}_{2} \mathrm{O}\right.$ dan $\left.\mathrm{KCl}\right)$, bahan organik, fosfor, dan kalium. Bahan organik dengan menggunakan metode Walkley and Black, $\mathrm{pH}\left(\mathrm{H}_{2} \mathrm{O}\right.$ dan $\left.\mathrm{KCl}\right)$ diukur dalam suspensi tanah-air 1: 5 menggunakan elektroda gelas, $\mathrm{P}$ total dan $\mathrm{P}$ larut diukur secara kolorimetri, diekstraksi menggunakan metode $\mathrm{HCl} 25 \%$ dan Olsen. K Total menggunakan $\mathrm{HCl} 25 \%$ dengan Spektrometri (Soil Research Institute 2009).

\section{HASIL DAN PEMBAHASAN \\ Sifat Kimia Tanah}

Sifat-sifat kimia tanah disajikan pada Tabel 1. Kesuburan kimia tanah yang diambil pada tahun 2018 lebih baik dari pada tahun 2017 termasuk $\mathrm{pH}$, C-organik, N-total, $\mathrm{P}$ dan $\mathrm{K}$ diekstraksi dengan $\mathrm{HCl}$ $25 \%$. Penemuan yang sama dilaporkan oleh Syukur (2005). Tahun 2018, pH tanah netral dalam budidaya padi organik dan semi organik, tetapi pada budidaya padi konvensional cenderung sedikit asam. $\mathrm{pH}$ netral disebabkan oleh bahan organik, sedangkan pada budidaya konvensional agak asam karena pupuk. Tingkat karbon organik tanah (SOC) diklasifikasikan tinggi dalam sistem budidaya padi organik dan semi organik. Menurut Sommerfeldt et al. (1988) dan Clark et al. (1998), pengaplikasian pupuk kandang dan tanaman penutup memiliki bahan organik yang lebih tinggi. Total $\mathrm{N}$ tanah dalam sistem organik, semi 
organik dan konvensional tergolong medium karena adanya penambahan bahan organik (pupuk kandang dan kompos) dalam budidaya organik dan semi organik, dan karena pemberian urea dan kompos dalam budidaya padi secara konvensional. Pada tahun 2018, KTK tanah di lahan organik $\left(38,40 \mathrm{cmol} . \mathrm{kg}^{-1}\right)$ lebih baik dari pada di semi organik $\left(15,73 \mathrm{cmol} \mathrm{kg}^{-1}\right)$ dan pertanian padi konvensional $\left(13,38 \mathrm{cmol} \mathrm{kg}^{-1}\right)$ dan semi organik lebih tinggi daripada sistem konvensional. Hal ini disebabkan karena petani memberikan bahan organik yang berbeda dan dosis yang berbeda (pupuk kandang dan jerami) yang dapat membangun koloid tanah.

Tabel 1. Dinamika kesuburan kimia tanah pada ketiga budidaya padi di Desa Termes, Sambung Macan, Kabupaten Sragen

\begin{tabular}{crrrrrc}
\hline \multirow{2}{*}{ Parameter } & \multicolumn{2}{c}{ Organik } & \multicolumn{2}{c}{ Semi organik } & \multicolumn{2}{c}{ Konvensional } \\
\cline { 2 - 7 } & 2017 & 2018 & 2017 & 2018 & 2017 & 2018 \\
\hline $\mathrm{pH}_{\text {(H20) }}$ & 6,9 & 7,63 & 6,6 & 7,56 & 6,0 & 6,40 \\
C-Organik (\%) & 3,2 & 3,85 & 2,7 & 3,04 & 1,3 & 2,61 \\
N-Total (\%) & 0,28 & 0,43 & 0,25 & 0,37 & 0,17 & 0,33 \\
P extracted with & 62,3 & 134 & 48,9 & 90 & 41,7 & 81 \\
$25 \% \mathrm{HCl}(\mathrm{ppm})$ & & & & & & \\
$\mathrm{K}$ extracted with & 37,7 & 170 & 32,3 & 65 & 19,7 & 64 \\
$25 \% \mathrm{HCl}(\mathrm{ppm})$ & & & & 15,73 & & 13,38 \\
$\mathrm{KTK}(\mathrm{cmol} / \mathrm{kg})$ & & 38,40 & &
\end{tabular}

Ketiga sistem budidaya padi (organik, semi organik, dan konvensional), $\mathrm{P}$ yang diekstraksi dengan $\mathrm{HCl} 25 \%$ tergolong sangat tinggi. Hal ini menunjukkan bahwa pemberian pupuk mineral dalam sistem budidaya konvensional ataupun penggunaan 3 ton pupuk kandang ha ${ }^{-1}$ musim $^{-1}$ oleh petani pada budidaya padi organik dapat meningkatkan ketersediaan $P$. Sementara, $\mathrm{P}$ yang diekstraksi dengan $\mathrm{HCl} 25 \%$ dalam sistem pertanian padi konvensional juga dianggap tinggi, ini menunjukkan aplikasi 100 hingga $150 \mathrm{~kg} \mathrm{SP}$ 36 ha $^{-1}$ musim $^{-1}$ yang dilakukan oleh petani dapat meningkatkan ketersediaan $\mathrm{P}$. Total $\mathrm{K}$ dalam budidaya organik padi dianggap sangat tinggi, lebih tinggi dari pada budidaya padi secara semi organik dan konvensional. Hal ini menunjukkan bahwa aplikasi 3 ton ha $^{-1}$ musim $^{-1}$ pupuk kandang sudah cukup untuk meningkatkan total $\mathrm{K}$ dalam tanah. Hal ini menunjukkan kompos jerami memiliki kandungan $\mathrm{K}$ yang tinggi. Penambahan sekitar $50 \mathrm{~kg} \mathrm{KCl} \mathrm{ha}^{-1}$ musim $^{-1}$ (budidaya konvensional) tidak lebih baik dari pemberian kompos jerami sebanyak 3 ton ha- ${ }^{-1}$ musim $^{-1}$ (budidaya organik) di Sambiredjo, Sragen (Sukristiyonubowo et al. 2018; Clark et al. 1998; Rasmussen dan Parton 1994; Wander et al. 1994).

Dapat disimpulkan bahwa pada tahun 2018 budidaya padi organik secara umum lebih baik dibandingkan dengan budidaya padi semi organik dan konvensional termasuk $\mathrm{pH}$, C-organik, kandungan nitrogen, dan $\mathrm{P}$, dan $\mathrm{K}$ diekstraksi dengan $25 \% \mathrm{HCl}$. Lebih lanjut, dalam budidaya padi konvensional, pemberian pupuk mineral yang tepat untuk meningkatkan kesuburan tanah yang mengarah pada hasil padi adalah suatu keharusan. Tahun 2017, secara umum kesuburan kimia tanah di lahan organik lebih baik dibandingkan pada semi organik dan konvensional, dan semi organik lebih baik daripada pertanian padi konvensional termasuk $\mathrm{pH}$, C-organik, $\mathrm{N}$-total, $\mathrm{P}$ dan $\mathrm{K}$ yang diekstraksi dengan $\mathrm{HCl} 25 \%$.

\section{Produksi Biomasa Padi}

Budidaya padi organik pada tahun 2017 menunjukkan produksi biomassa padi tertinggi yaitu residu beras, jerami padi, dan produksi gabah (Tabel 2). Dalam produksi gabah, teknologi ini juga menunjukkan perbedaan nyata dengan perlakuan lainnya. Produksi biomasa padi mencapai sekitar $4,48 \pm 0,08 ; 9,04 \pm 0,13$ dan $6,80 \pm 0,12$ ton ha ${ }^{-1}$ musim $^{-1}$ untuk residu panen, jerami padi, dan gabah, demikian juga pada tahun 2018 menunjukkan produksi biomasa padi yang tertinggi, yaitu $3,58 \pm 0,75$; $8,47 \pm 0.65$ dan $7,86 \pm 0,75$ ton ha $^{-1}$ musim $^{-1}$ masing-masing untuk residu panen, jerami dan gabah (Tabel 2).

Tabel 2. Produksi biomasa padi pada budidaya padi organik, semi organik dan konvensional di Dusun Termas, Kecamatan Sambung Macan, Kabupaten Sragen

Produksi Biomasa Padi (ton ha-1 musim $^{-1}$ )

\begin{tabular}{lcccccc}
\cline { 2 - 6 } Perlakuan & \multicolumn{2}{c}{ Gabah } & \multicolumn{2}{c}{ Jerami } & \multicolumn{2}{c}{ Rice Residues } \\
\cline { 2 - 7 } & 2017 & 2018 & 2017 & 2018 & 2017 & 2018 \\
\hline Organik & $6.80 \pm 0,12 \mathrm{a}$ & $7,86 \pm 0,75 \mathrm{a}$ & $9.04 \pm 0,13 \mathrm{a}$ & $8,47 \pm 0.65 \mathrm{a}$ & $4,48 \pm 0.08 \mathrm{a}$ & $3,58 \pm 0,75 \mathrm{a}$ \\
Semi organik & $6.40 \pm 0,40 \mathrm{a}$ & $6,45 \pm 0,50 \mathrm{~b}$ & $8.67 \pm 0,67 \mathrm{ab}$ & $8,21 \pm 0.98 \mathrm{a}$ & $3.24 \pm 0,10 \mathrm{a}$ & $3,25 \pm 0.44 \mathrm{a}$ \\
Konvensional & $6.07 \pm 0,25 \mathrm{ab}$ & $3,07 \pm 0,70 \mathrm{c}$ & $8.63 \pm 0.45 \mathrm{ab}$ & $7,97 \pm 0,21 \mathrm{~b}$ & $2.92 \pm 0,15 \mathrm{~b}$ & $2,88 \pm 0,13 \mathrm{~b}$ \\
\hline
\end{tabular}


Dibandingkan dengan sistem pertanian padi konvensional, pada tahun 2017 meningkat sekitar $0,73 \mathrm{t} \mathrm{ha}^{-1}$ musim $^{-1}$ atau $61 \%, 0,41 \mathrm{t} \mathrm{ha}^{-1}$ sedangkan pada tahun 2018, kenaikannya berkisar 4,79 ton ha-1 musim $^{-1}$ atau $156 \% ; 0,5$ ton ha $^{-1}$ musim $^{-1}$ atau $6 \%$ dan 0,7 ton ha ${ }^{-1}$ musim $^{-1}$ atau $24 \%$ masing-masing untuk gabah, jerami padi dan sisa panen. Hal ini disebabkan dalam budidaya padi organik kualitas tanah termasuk kesuburan kimia tanah, fisik dan biologis lebih baik dari pada keduanya sistem budidaya padi, yaitu semi organik dan konvensional. Jika dibandingkan antara budidaya konvensional dengan semi organik, terjadi peningkatannya adalah 0,33 ton, 0,04 ton dan 0,32 ton ha $^{-1}$ musim $^{-1}$ masing-masing untuk gabah, jerami dan sisa panen pada tahun 2017, sedangkan pada tahun 2018 berkisar antara 3,38 ton; 0, 24 ton dan 0,37 ton ha ${ }^{-1}$ musim $^{-1}$ masing-masing untuk gabah, jerami dan sisa panen.

\section{KESIMPULAN}

Dapat disimpulkan bahwa secara umum terjadi peningkatan kesuburan tanah dari tahun 2017 ke tahun 2018 baik pada budidaya padi organik, semi organik dan konvensional. Peningkatan $\mathrm{pH}$, C-organik, kandungan nitrogen, dan $\mathrm{P}, \mathrm{K}$ diekstraksi dengan $25 \%$ $\mathrm{HCl}$ dan hasil biomasa padi tertinggi pada budidaya organik.

\section{DAFTAR PUSTAKA}

Alice J, Sujeetha RP, Venugopal MS. 2003. Effect of Organic Farming on Management of Rice Brown Plant Hopper. IRRN. 28 (2): $36-37$.

Chino M, Hayashi M, Fukumorita T. 1987. Chemical Composition of Rice Phloem Sap and its Fluctuation. J. Plant Nutr 10: 1651-1661.

Clark MS, Horwath WR, Shennan C, Scow KM. 1998. Changes in Soil Chemical Properties Resulting from Organic and Low-Input Farming Practices. Agronomy Journal. 90: 662-671.

Hansen B, Kristensen ES, Grant R, Hogh Jensen H, Simmelsgaard SE, Olesen JE. 2000. Nitrogen leaching from conventional versus organic farming systems- a system modelling approach. European Journal of Agronomy. 13:65-82.

Hasegawa H, Furukawa Y, Kimura SD. 2005. On-farm Assessment of Organic Amendments Effects on Nutrient Status and Nutrient Use Efficiency of Organic Rice Fields in Northern Japan. Agriculture, Ecosystems and Environment. 108:350-362.

Kajimura T, Fujisaki K, Nagasuji F. 1995. Effect of Organic Rice Farming on Leafhoppers and Plant Hoppers and Amino Acid Contents in Rice Phloem Sap and Survival Rate of Plant Hoppers. Applied Entomology Journal. 30:12-22.
Mäder P, Fliessbach A, Dubois D, Gunst L, Fried P, Niggli U. 2002. Soil Fertility and Biodiversity in Organic Farming. Science, 296, 1694-1697.

Oehl F, Sieverding E, Mäder P, Dubois D, Ineichen K, Boller T, Wiemken A. 2004. Impact of long-term conventional and organic farming on the diversity of arbuscular mycorrhizal fungi. Oecologia. 138: 574-583.

Prakhas YS, Bhadoria PBS, Rakshit A. 2002. Relative Efficacy of Organic Manure in Improving Milling and Cooking Quality of Rice. IRRN. 27(1):43 - 44.

Rasmussen PE, Parton WJ. 1994. Long-term Effects of Residue Management in Wheat-fallow: I. Inputs, Yields and Soil Organic Matter. Soil Science Society of America Journal. 58:523-530.

Rigby D, Caceres D. 2001. Organic Farming and The Sustainable Agricultural Systems. Agricultural Systems, 68, 21-40. DOI: $10.1016 / S 0308-521 X(00) 00060-3$.

Soil Research Institute. 2009. Penuntun Analisa Kimia Tanah, Tanaman, Air dan Pupuk (Procedure to Measure Soil Chemical, Plant, Water and Fertilizer). Soil Research Institute, Bogor. 234 p. (in Indonesian).

Sommerfeldt TG, Chang C, Entz T. 1988. Long-term Annual Manure Applications Increase Soil Organic Matter and Nitrogen and Decrease Carbon to Nitrogen Ratio. Soil Science Society of America Journal 52:1668-1672.

Stolze M, Piorr A, Harring A, Dabbert S. 2002. The Environmental Impact of Organic Farming in Europe. Organic Farming in Europe: Economics and Policy. Vol 6. University of Hohenheim, Germany.

Sukristiyonubowo, Benito HP, Edi H. 2015. Soil properties under organic versus conventional vegetables farming systems in Bogor District. Indonesian Soil and Climate Journal 39 (1): 19 - 24.

Sukristiyonubowo, Rahmat AP, Damasus R. 2018. Soil Chemical-physical Characteristic and Rice Biomass Production of Three Rice Farming Systems in Sragen Regency. Soil and Climate Journal 1: 51-56.

Syukur A. 2005. The Effect of Organic Matter of Soil Properties and Caisim Growth in Soil Sandy Land. Soil Science and Environment Journal. Vol. 5 (1); p.30-38.

Wander MM, Traina SJ, Stinner BR, Peters SE. 1994. Organic and conventional management effects on biologically active organic matter pools. Soil Science Society of America Journal 58: 1130-1139. 